\title{
SUPERVISI AKADEMIK BERKELANJUTAN DALAM MENINGKATKAN KOMPETENSI GURU PADA PENYUSUNAN SILABUS DAN RPP
}

\author{
Iis Jenab \\ SD Negeri Cibabat Mandiri 4 , Cimahi, Jawa Barat, Indonesia \\ iisjenab64@gmail.comid
}

\begin{abstract}
ABSTRAK
Penyusunan perangkat pembelajaran seperti silabus dan rencana pelaksanaan pembelajaran (RPP) oleh guru-guru di SDN Cibabat mandiri 4 belum maksimal. Oleh karen itu, pada penelitian ini dilaksankan penelitian dengan judul supervisi akademik yang berkelanjutan dalam meningkatkan kompetensi guru dalam menyusun perangkat pembelajaran. Tujuan dari penelitian ini adalah untuk meningkatkan pemahaman guru-guru di lingkungan SDN Cibabat mandiri 4 dalam membuat perangkat pembelajaran. Metode yang digunakan pada penelitian ini adalah metode penelitian tindakan sekolah dengan instrumen observasi. Hasil penelitiannya adalah terdapat peningkatan kemampuan guru-guru SDN Cibabat mandiri 4 dalam menyusun perangkat pembelajaran.
\end{abstract}

Kata Kunci : supervisi, kompetensi guru

\begin{abstract}
Preparation of learning tools such as silabus and plans for implementing learning by teachers at SDN Cibabat mandiri 4 has not been maximized. Therefore, in this study, research was carried out with an ongoing academic supervision title in improving teacher competencies in compiling learning devices. The purpose of this study was to improve the understanding of teachers in SDN Cibabat mandiri 4 in making learning devices. The method used in this study is the method of school action research with observation instruments. The results of his research are that there is an increase in the ability of SDN Cibabat mandiri 4 teachers in compiling learning devices.
\end{abstract}

Kata Kunci : supervision, teacher competence

\section{PENDAHULUAN}

Pendidikan adalah proses perubahan manusia menjadi lebih baik, lebih mahir dan lebih terampil. Oleh karena itu, pelaksanaan pendidikan jharus terus dikembangkan dengan baik oleh setiap pihak yang telibat dalam dalam dunia pendidikan Septiyan (2017). Untuk mencapai tujuan tersebut tentunya dibutuhkan strategi yaitu dengan strategi pembelajaran. Dalam strategi pembelajaran terkandung tiga hal pokok yakni perencanaan, pelaksanaan, dan evaluasi. Perencanaan program berfungsi untuk memberikan arah pelaksanaan pembelajaran sehingga menjadi terarah dan efesien. Salah satu bagian dari perencanaan pembelajaran yang sangat penting dibuat oleh guru sebagai pengarah pembelajaran adalah silabus dan Rencana Pelaksanaan Pembelajaran (RPP). Silabus memberikan arah tentang apa saja yang harus dicapai guna menggapai tujuan pembelajaran dan cara seperti apa yang akan digunakan. Selain itu silabus juga memuat tehnik penilaian seperti untuk menguji sejauh mana keberhasilan pembelajaran.Rencana Pelaksanaan pembelajaran (RPP) adalah instrumen perencanaan yang lebih spesifik dari silabus. Rencana Pelaksanaan 
pembelajaran ini dibuat untuk membantu guru dalam mengajar agar tidak melebar jauh dari tujuan pembelajaran.

Dengan melihat pentingnya penyusunan Pelaksanaan pembelajaran ini, guru semestinya tidak mengajar tanpa adanya rencana. Namun sayang perencanaan pembelajaran yang mestinya dapat diukur oleh kepala sekolah ini, tidak dapat diukur oleh kepala sekolah karena hanya direncanakan dalam pikiran sang guru saja. Akibatnya kepala sekolah sebagai pembuat kebijakan di sekolah tidak dapat mengevaluasi kinerja guru secara akademik. Kinerja yang dapat dilihat oleh kepala sekolah hanyalah kehadiran tatap muka, tanpa mengetahui apakah kemampuan guru dalam mengelola pembelajaran sudah sesuai dengan harapan atau belum, atau sudah kompetensi dasar yang harus dikuasai oleh siswa terkuasai dengan benar. Hasil pengamatan di tahun pelajaran 2018/2019 di SD Negeri Cibabat mandiri 4 Kecamatan Cimahi Utara Kota Cimahi didapatkan data sebagai berikut: 1. Hanya $60 \%$ guru yang menyusun silabus dan RPP

2. Secara kualitas, silabus dan RPP yang baik baru mencapai angka 30\% dari silabus dan RPP yang dibuat oleh guru.

Untuk mengatasi permasalahan tersebut, peneliti yang berkedudukan sebagai kepala sekolah di atas merencanakan untuk melakukan supervisi akademik yang berkelanjutan. Dengan metode tersebut diharapkan setelah kegiatan ini, guru yang menyusun silabus dan RPP meningkat menjadi 90\% dan kualitas silabus dan RPP yang baik menjadi $80 \%$.

Dari hasil identifikasi masalah yang muncul, peneliti akan membatasi permasalahan yang disinyalir oleh peneliti sebagai akar permasalahan dari semua masalah yang diidentifikasi yaitu rendahnya kompetensi dan kinerja guru dalam menyusun rencana pembelajaran khususnya silabus dan RPP di SDN Cibabat Mandiri 4 Kota Cimahi.

\section{Kompetensi Guru}

Majid ( 2005: 6) menjelaskan kompetensi yang dimiliki oleh setiap guru akan menunjukkan kualitas guru dalam mengajar. Kompetensi tersebut akan terwujud dalam bentuk penguasaan pengetahuan dan profesional dalam menjalankan fungsinya sebagai guru. Kompetensi yang diperlukan oleh seseorang tersebut dapat diperoleh baik melalui pendidikan formal maupun pengalaman. Menurut Undang-undang No.14 tahun 2005 tentang Guru dan Dosen pasal 10 ayat (1) kompetensi guru meliputi kompetensi pedagogik , kompetensi kepribadian, kompetensi sosial, dan kompetensi profesional yang diperoleh melalui pendidikan profesi. Salah satu kompetensi yang wajib dimiliki oleh seorang guru seperti diamanatkan dalam Peratuaran Pemerintah di atas adalah kompetensi pedagogik.

Dalam Undang-undang No.14 Tahun 2005 tentang Guru dan Dosen dikemukakan kompetensi pedagogik adalah kemampuan mengelola pembelajaran peserta didik. Depdiknas (2004: 9) menyebut kompetensi ini dengan kompetensi pengelolaan pembelajaran. Kompetensi ini dapat dilihat dari kemampuan merencanakan program belajar mengajar, kemampuan melaksanakan interaksi atau mengelola proses belajar mengajar, dan kemampuan melakukan penilaian. Seperti uraian di atas, unsur pertama dalam kompetensi pedagogik seorang guru adalah kemampuan merencanakan program belajar mengajar. Depdiknas (2004: 9) mengemukakan kompetensi 
penyusunan rencana pembelajaran meliputi :

1. Mampu mendeskripsikan tujuan;

2. Mampu memilih materi;

3. Mampu mengorganisir materi;

4. Mampu menentukan metode/ setrategi pembelajaran;

5. Mempu menentukan sumber belajar/ media/alat peraga pembelajaran;

6. Mampu menyusun perangkat penilaian;

7. Mampu menentukan teknik penilaian ,dan

8. Mampu mengalokasikan waktu.

Berdasarkan uraian di atas, merencanakan program belajar mengajar merupakan proyeksi guru mengenai kegiatan yang harus dilakukan siswa selama pembelajaran berlangsung, yang mencakup: merumuskan tujuan, menguraikan deskripsi satuan bahasan, merancang kegiatan belajar mengajar, memilih berbagai media dan sumber belajar, dan merencanakan penilaian penguasaan tujuan. Perangkat perencanaan pembelajaran yang mengandung unsur-unsur tersebut di atas dan merupakan perangkat pembelajaran paling utama adalah silabus pembelajaran dan Rencana Pelaksanaan Pembelajaran.

\section{Kinerja Guru (Mengajar Guru)}

Mangkunegara (2002:

mengemukakan bahwa kinerja adalah hasil kerja secara kualitas dan kuantitas yang dicapai oleh seorang pegawai dalam melaksanakan tugasnya sesuai dengan tanggung jawab yang diberikan kepadanya. Pendapat lain dikemukakan oleh Irawan (Sedarmayanti, 2004 : 177) bahwa kata kunci dari definisi kinerja adalah hasil kerja pekerja, proses atau organisasi, terbukti secara kongkrit, dapat diukur, dapat dibandingkan dengan standar yang telah ditentukan. Lebih lanjut dikemukakan kinerja dapat dirumuskan sebagai unjuk kerja yang dicapai, berupa prestasi (kualitas individu) yang diperlihatkan (tampilan atau unjuk kerja) dibidang yang menjadi tanggung jawabnya (tugas fungsional) dalam bentuk kemampuan kerja. Guru sebagai ujung tombak pelaksanaan tugas, fungsi sekolah adalah seorang guru yang profesioanal. Artinya seorang guru dituntut untuk dapat melaksanakan tugas pengajaran, guru harus menguasai ilmu yang diajarakan, menguasai berbagai metode pengajaran, dan mengenal anak didiknya baik secara lahiriah atau batiniah (memahami setiap anak). Dalam pengenalan anak, guru dituntut untuk mengetahui latar belakang kehidupan anak, lingkungan anak, dan tentunya mengetahui kelemahan-kelemahan anak secara psikologis.Untuk itu guru harus dapat menjadi seorang "dokter" yang dapat melakukan "diagnosa" untuk menemukan kelemahan-kelemahan si anak sebelum mengajarkan ilmu yang telah dikuasainya. Setelah itu baru dia akan memilih metode atau mengulangi suatu topik sebagai dasar untuk memudahkan pemahaman si anak terhadap ilmu yang akan diajarkan. Untuk itu dituntut kreativitas guru, keprofesionalan guru, memegang etika guru dan tentunya dedikasi yang tinggi untuk melaksanakan tugas keguruannya. Jika hal ini dilakukan oleh masing-masing guru maka benarlah bahwa pekerjaan guru adalah pekerjaan professional yang tak mungkin dapat dilakukan oleh orang lain.

Zainal Aqib (2002 : 81) menggambarkan lingkaran tugas guru dalam mempersiapkan, melaksanakan dan memperbaiki kinerja mengajar di kelas dapat dilihat pada gambar 1 berikut. 


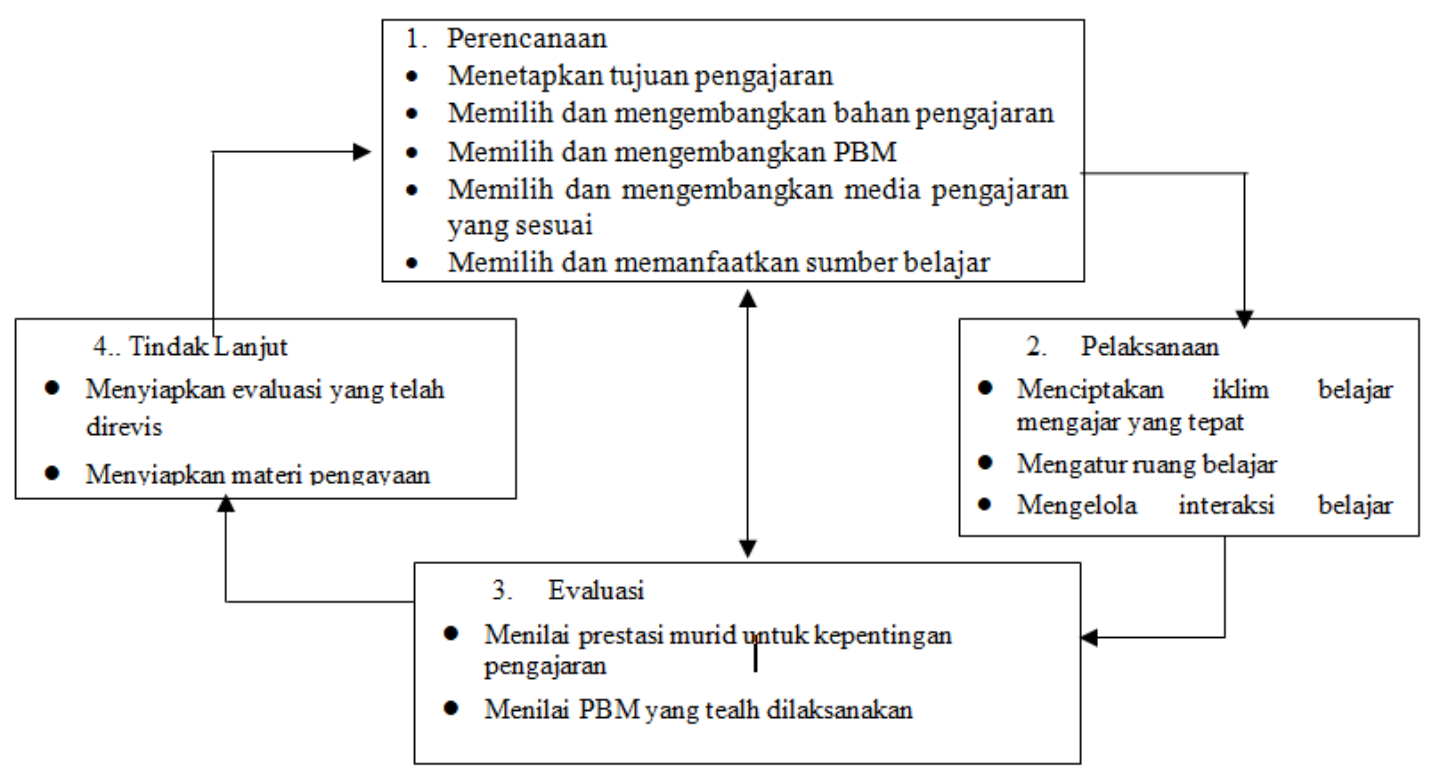

Gambar 1. Lingkaran tugas guru dalam mempersiapkan, melaksanakan dan memperbaiki kinerja mengajar

Dari gambar diatas dapat dijelaskan bahwa tahapan perencanaan sampai tindak lanjut merupakan suatu proses yang berurutan (garis lurus). Tetapi masing-masing tahapan tersebut saling memberikan konstribusi (garis putusputus ) dalam pelaksanaan tahapan yang selanjutnya. Sehingga dapat diperoleh suatu proses belajar mengajar. Mengajar yang terus diperbaiki demi mendapatkan kinerja mengajar yang optimal.

\section{Tupoksi Kepala Sekolah}

Dalam implementasi MBS, kepala sekolah merupakan "the key person" keberhasilan peningkatan kualitas pendidikan di sekolah. Ia adalah orang yang diberi tanggung jawab untuk mengelola dan memberdayakan berbagai potensi masyarakat serta orang tua untuk mewujudkan visi, misi dan tujuan sekolah. Oleh karena itu dalam implementasi MBS kepala sekolah harus memiliki visi, misi dan wawasan yang luas tentang sekolah yang efektif serta kemampuan profesional dalam mewujudkannya melalui perencanaan, kepemimpinan, manajerial dan supervisi pendidikan. Ia juga dituntut untuk menjalin kerjasama yang harmonis dengan berbagai pihak yang terkait dengan program pendidikan di sekolah. Singkatnya, dalam implementasi MBS kepala sekolah harus mampu berperan sebagai berikut:

1. Kepala sekolah sebagai edukator

2. Kepala sekolah sebagai manajerial

3. Kepala sekolah sebagai administrator

4. Kepala sekolah sebagai supervisor

5. Kepala sekolah sebagai leader

6. Kepala sekolah sebagai innovator

7. Kepala sekolah sebagai motivator

\section{Supervisi Akademik}

\section{Pengertian Supervisi}

Konsep supervisi modern dirumuskan oleh Dahono (2015) supervisi adalah "Bantuan dalam pengembangan situasi pembelajaran yang lebih baik". Rumusan ini mengisyaratkan bahwa layanan supervisi meliputi keseluruhan situasi belajar mengajar. Situasi belajar inilah yang seharusnya diperbaiki dan ditingkatkan melalui layanan kegiatan supervisi. Dengan demikian layanan supervisi tersebut mencakup seluruh aspek dari penyelenggaraan pendidikan dan pengajaran. Konsep supervisi tidak 
bisa disamakan dengan inspeksi, inspeksi lebih menekankan kepada kekuasaan dan bersifat otoriter, sedangkan supervisi lebih menekankan kepada persahabatan yang dilandasi oleh pemberian pelayanan dan kerjasama yang lebih baik diantara guru-guru, karena bersifat demokratis. Istilah supervisi pendidikan dapat dijelaskan baik menurut asal usul (etimologi), bentuk perkataannya (morfologi), maupun isi yang terkandung dalam perkataan itu (semantik).

\section{METODE}

Metode penelitian yang digunakan dalam penelitian ini adalah metode penelitian tindakan sekolah (PTS). Metode penelitian tindakan sekolah kajian sistematik dan upaya perbaikan pelaksanaan praktek pendidikan oleh kepala sekolah dengan melakukan tindakan-tindakan dalam upaya meningkatkan kompetensi guru-guru. Penelitian ini dilaksanakan di SD Negeri Cibabat Mandiri 4 Kecamatan Cimahi Utara Kota Cimahi. Penelitian dilaksanakan pada guru-guru dengan tujuan agar guru-guru dapat memanfaatkan teknologi yang dapat membantu pengolahan nilai dalam hal ini menggunakan MS. Excel.

\section{HASIL DAN PEMBAHASAN Kondisi Awal}

Berdasarkan hasil pemantauan melalui supervisi akademik dan hasil dari penelitian eksplorasi di SDN Cibabat Mandiri 4 masih ditemukan guru yang mengajar belum mengkaji ulang pengembangan silabus dan pengembangan Rencana Pelaksanaan Pembelajaran (RPP) untuk kompetensi yang akan diajarkan, sehingga dalam pelaksanaan proses pembelajaran tidak terrencana dengan baik, karena itu bisa saja terjadi materi yang berulang-ulang diberikan pada siswa, sedangkan kompetensi yang lain tidak tersampaikan secara keseluruhan, sehingga siswa-siswapun menilai bahwa guru mengajar kurang menguasai materi,. Ada sebagian guru memiliki rencana pembelajaran lengkap, tetapi dengan cara memfotokopi dari sekolah lain yang situasi dan kondisinya berbeda, baik guru, siswa maupun sarana dan prasarananya, karena yang membuat orang lain pemikiran dan ideidenya juga bisa saja berbeda, sehingga rencana pembelajaran yang telah ada tidak bisa dilaksanakan dengan sebaikbaiknya. Sebagai dampak dari tidak/belum disusunnya rencana pembelajaran, maka metode dan model pembelajaran yang digunakan pun tidak terencana dengan baik, dan metode yang paling mudah tanpa adanya persiapan khusus yaitu digunakannya metode ceramah. Akibat selanjutnya siswa menjadi pasif, kurang antusias, mengantuk, ngobrol sendiri dan ada pula yang mengerjakan mata pelajaran lain. Sedangkan bagi yang memfotocopi silabus dan Rencana Pelaksanaan Pembelajaran dari sekolah lain sebagian besar tidak bisa diterapkan, karena memang situasi dan kondisinya berbeda. Sebenarnya dengan diterapkannya Kurikulum Tingkat Satuan Pendidikan (KTSP), sekolah diberi otoritas penuh untuk melaksanakan kurikulum disesuaikan dengan situasi dan kondisi sekolah masing-masing, tanpa merubah substansi dan esensi dari kurikulum yang telah disusun oleh Badan Standar Nasional Pendidikan (BSNP).

\section{Siklus 1}

1. Perencanaan

Sebelum melaksanakan proses pembelajaran, terlebih dahulu guru harus menyusun perencanaan pembelajaran yaitu silabus dan Perencanaan Pelaksanaan Pembelajaran (RPP). Untuk mengetahui sejauh mana 
guru telah memahami dalam penyusunan silabus dan RPP, peneliti melakukan penelitian eksplorasi tentang administrasi/perangkat pembelajaran secara umum melalui angket yang diberikan pada semua guru kelas dan hasil supervisi akademik. Hasil supervisi akademik yaitu hasil supervisi Kepala Sekolah terhadap guru dalam melaksanakan pembelajaran di dalam kelas, yang merupakan implementasi dari Rencana Pelaksanaan Pembelajaran (RPP) yang telah disiapkan sebelumnya.

Untuk lebih jelasnya, peneliti sajikan hasil dari penelitian eksplorasi pada tabel 4.1, yaitu sebagai berikut :

Tabel 4.1 Distribusi Prosentase Hasil Penelitian Eksplorasi Lembar Observasi Guru (LOG) Tentang Perangkat Pembelajaran Guru Kelas di SDN Cibabat Mandiri 4

\begin{tabular}{|c|c|c|}
\hline No & Kegiatan & Ketercapaian \\
\hline 1 & Membuat program tahunan & $75 \%$ \\
\hline 2 & Membuat program semester & $75 \%$ \\
\hline 3 & Membuat program harian & $25 \%$ \\
\hline 4 & Menyusun pengembangan silabus sendiri & $25 \%$ \\
\hline 5 & $\begin{array}{l}\text { Memfotocopi/mengeprint silabus yang sudah } \\
\text { ada }\end{array}$ & $75 \%$ \\
\hline 6 & Menyusun pengembangan semua RPP & $25 \%$ \\
\hline \multirow[t]{2}{*}{7} & Memfotokopi pengembangan Rencana & $75 \%$ \\
\hline & Pelaksanaan Pembelajaran dari sekolah lain & \\
\hline 8 & Membuat daftar nilai harian & $100 \%$ \\
\hline 9 & Membuat daftar nilai tugas & $75 \%$ \\
\hline 10 & Membuat daftar hadir & $100 \%$ \\
\hline 11 & Membuat agenda pelaksanaan harian & $25 \%$ \\
\hline 12 & Membuat analisis butir soal & $25 \%$ \\
\hline 13 & Membuat analisis hasil ulangan dan daya serap & $100 \%$ \\
\hline 14 & Membuat program remedial & $50 \%$ \\
\hline 15 & Membuat program pengayaan & $50 \%$ \\
\hline 16 & Membuat kisi-kisi soal & $25 \%$ \\
\hline 17 & Membuat lembar kerja siswa (LKS) & $50 \%$ \\
\hline 18 & Membuat kumpulan tugas & $75 \%$ \\
\hline 19 & Membuat kumpulan soal-soal & $100 \%$ \\
\hline 20 & Membuat catatan insidental & $25 \%$ \\
\hline 21 & Membuat daftar buku pegangan & $100 \%$ \\
\hline
\end{tabular}

Dari tabel di atas diketahui bahwa sebagian besar guru belum memiliki administrasi pembelajaran yang lengkap, tetapi dalam penelitian ini peneliti hanya membatasi dalam hal penyusunan pengembangan silabus dan RPP saja, yang sangat penting dikuasai oleh semua guru. Dari hasil tabel diatas menunjukkan bahwa guru belum mengembangkan silabus sendiri, tetapi baru sebatas memfotocopi/mengeprint silabus yang sudah ada dari Badan
Standar Nasional Pendidikan (BSNP) yaitu sebanyak $75 \%$, sedangkan yang sudah memiliki semua RPP dalam arti membuat sendiri baru $25 \%$ dan yang hanya memfotocopi dari sekolah lain sebanyak $75 \%$.

Berdasarkan data di atas, secara umum administrasi pembelajaran guru kelas di SDN Cibabat Mandiri 4 masih kurang, tetapi pada penelitian ini dibatasi hanya pembinaan tentang penyusunan pengembangan silabus dan Rencana 
Pelaksanaan Pembelajaran (RPP), pembinaan penyusunan pengembangan silabus dilaksanakan pada siklus I dengan 2 kali pertemuan dengan alasan silabus merupakan dasar untuk penentuan indikator dan materi ajar pada penyusunan pengembangan Rencana Pelaksanaan Pembelajaran (RPP), sedangkan pengembangan penyusunan RPP akan dilaksanakan pada siklus II dengan 2 kali pertemuan. Untuk pelaksanaannya direncanakan melalui tindakan yang dilakukan oleh Kepala Sekolah sebagai peneliti dan Kepala Sekolah lain sebagai kolaborator yang mengobservasi peneliti selama pembinaan berlangsung.

\section{Pelaksanaan}

Berdasarkan perencanaan siklus I, bahwa tindakan yang dilakukan oleh peneliti terhadap guru yaitu melalui Pembinaan, pelatihan, sosialisasi, diskusi dan pemodelan untuk memahami silabus. Tindakan yang dilakukan oleh guru adalah mengimplementasikan hasil kegiatan di atas dengan menyusun pengembangan silabus dengan melihat standar isi (SI) dan standar kompetensi lulusan (SKL). Dalam Pembinaan dan pelatihan ini lebih menitik beratkan pada mencermati dan menganalisis Standar Isi untuk dijabarkan dalam komponen silabus. Hasil diskusi menunjukkan bahwa silabus yang telah dibuat sebelumnya masih memerlukan pembenahan atau revisi. Setelah melakukan pelatihan tersebut, peneliti memberikan kesempatan kepada guruguru untuk menyusun pengembangan silabus sendiri berdasarkan situasi dan kondisi serta sarana dan prasarana yang tersedia di sekolah, yaitu dengan membagikan format komponen silabus untuk diisi dan dikerjakan. Setelah selesai disusun silabus tersebut, dikumpulkan dan dianalisa oleh peneliti yang dimaksud kesesuaian dalam hal ini adalah sesuai dengan tuntutan silabus yang sudah ditetapkan. Hasil penyusunan pengembangan silabus bisa dilihat pada tabel 2 yaitu sebagai berikut :

Tabel 2. Distribusi Prosentase Hasil Observasi Kesesuaian Silabus Pada Siklus I, Pertemuan 1

\begin{tabular}{|c|c|c|c|c|}
\hline \multirow[b]{2}{*}{ No } & \multirow[b]{2}{*}{ Aspek Pengamatan } & \multicolumn{2}{|c|}{ Hasil Pengamatan } & \multirow[b]{2}{*}{ Keterangan } \\
\hline & & $\begin{array}{l}\text { Belum } \\
\text { Sesuai }\end{array}$ & Sesuai & \\
\hline 1 & Identitas & - & $100 \%$ & \\
\hline 2 & Standar Kompetensi & - & $100 \%$ & \\
\hline 3 & Kompetensi Dasar & - & $100 \%$ & \\
\hline 4 & Materi Ajar & $50 \%$ & $50 \%$ & \\
\hline 5 & Kegiatan Pembelajaran & $75 \%$ & $25 \%$ & \\
\hline 6 & Indikator & $75 \%$ & $25 \%$ & \\
\hline 7 & Jenis Penilaian & $50 \%$ & $50 \%$ & \\
\hline 8 & Alokasi Waktu & - & $100 \%$ & \\
\hline 9 & Sumber Belajar & $25 \%$ & $75 \%$ & \\
\hline
\end{tabular}

Dari tabel di atas dapat diketahui bahwa aspek materi ajar masih ada kesulitan dalam penyesuaian dengan standar isi dan standar kompetensi lulusan, yang sudah sesuai yaitu diperoleh $50 \%$, penentuan indikator hanya $25 \%$ dalam hal ini guru masih menemui kesulitan dalam mengembangkan kata-kata kerja operasional (KKO) yang bervariasi supaya keberhasilan bisa langsung 
terukur, Dalam menentukan jenis penilaian untuk mengukur indikator hanya $50 \%$ yang sudah sesuai sedangkan penentuan sumber belajar diperoleh baru diperoleh $75 \%$, yang ditemui dalam penentuan sumber belajar ini untuk referensi hanya menyebutkan sumber yang relevan, padahal diharapkan guru menuliskannya dengan lengkap sehingga orang lain yang membaca silabus tersebut, sudah bisa melihat sumber belajar yang tercantum dalam silabus dengan mudah. Sebagai contoh kalau sumber belajarnya adalah buku, maka jelas tertulis judul buku, karangan, penerbit, tahun terbit kalau perlu dengan halamannya. Tidak hanya dari buku atau media massa sumber belajarpun bisa melibatkan orang-orang yang ada dalam sistem sekolah, pemanfaatan sumber belajar dari lingkungan sekitarpun diperlukan dalam upaya menjadikan sekolah sebagai bagian integral dari masyarakat setempat.

Dalam pelaksanaan Pembinaan ini para guru sebagian besar begitu antusias terbukti dengan adanya beberapa guru yang mengajukan pertanyaan dan berdiskusi dengan sesama guru serta menyadari betapa perlunya mengembangkan sendiri silabus, dan menyadari kekeliruannya selama ini yang tidak hanya sebagai syarat administrasi saja, tetapi lebih memiliki arti penting dalam pelaksanaan proses pembelajaran sehingga apa yang akan dilaksanakan sudah terencana dan disesuaikan dengan situasi dan kondisi sekolah sendiri yaitu dengan menerapkan Kurikulum Tingkat Satuan Pendidikan, sehingga sekolah diberi keleluasaan untuk mengembangkan sendiri kurikulum tanpa mengurangi substansi standar isi.
Berdasarkan tabel distribusi prosentase hasil observasi kesesuaian penyusunan silabus, diketahui bahwa beberapa guru masih kesulitan menentukan materi ajar, penentuan indikator keberhasilan, jenis penilaian dan menentukan sumber belajar, maka disepakati diadakan pembinaan pada hari yang lain, dengan kesepakatan memilih kompetensi dasar yang lain, berbeda dari yang sudah dibuat pada pertemuan 1.

Menurut pengamatan dari kolaborator, peneliti sudah melaksanakan langkahlangkah Pembinaan Kolaboratif dengan sebaik-baiknya yang meliputi : mendengarkan, mempresentasikan, memecahkan masalah dan negoisasi, pelaksanaan kondusif antara guru-guru dengan pengawas sebagai peneliti.

Pelaksanaan siklus 1 pertemuan 2 oleh peneliti terhadap guru yaitu melalui pembinaan, pelatihan, sosialisasi, diskusi dan pemodelan untuk memahami silabus. Kegiatan ke dua ini dilaksanakan hari Sabtu tanggal 11 Agustus 2018. Pada pertemuan kedua ini terasa lebih santai karena lebih terbuka, bebas untuk bertanya dan mengeluarkan pendapat sehingga merasa senang, karena guru-guru tersebut tidak merasa sedang mendapatkan pembinaan, karena peneliti sendiripun sama-sama mengerjakan tugas membuat silabus walaupun dengan mata pelajaran yang berbeda. Tindakan yang dilakukan oleh guru adalah mengimplementasikan hasil kegiatan di atas dengan menyusun pengembangan silabus dengan melihat standar isi dan standar kompetensi lulusan. Setelah pengawas mendengarkan kesulitan yang dihadapi, pengawas kembali mempresentasikan jalan keluar mengatasi kesulitan yang dihadapi serta melakukan pelatihan, peneliti memberikan kesempatan kepada guru-guru untuk menyusun 
pengembangan silabus. Setelah selesai disusun silabus tersebut, dikumpulkan dan dianalisa oleh peneliti sebagai bahan pembahasan dalam refleksi pertemuan kedua.

Tabel 4.3 Distribusi Prosentase Hasil Observasi Kesesuaian Silabus Pada Siklus I, pertemuan 2

\begin{tabular}{|c|c|c|c|c|}
\hline \multirow[b]{2}{*}{ No } & \multirow[b]{2}{*}{ Aspek Pengamatan } & \multicolumn{2}{|c|}{ Hasil Pengamatan } & \multirow{2}{*}{ Keterangan } \\
\hline & & Belum Sesuai & Sesuai & \\
\hline 1 & Identitas & - & $100 \%$ & \\
\hline 2 & Standar Kompetensi & - & $100 \%$ & \\
\hline 3 & Kompetensi Dasar & - & $100 \%$ & \\
\hline 4 & Materi Ajar & $25 \%$ & $75 \%$ & \\
\hline 5 & Kegiatan Pembelajaran & $25 \%$ & $75 \%$ & \\
\hline 6 & Indikator & $25 \%$ & $75 \%$ & \\
\hline 7 & Jenis Penilaian & $25 \%$ & $75 \%$ & \\
\hline 8 & Alokasi Waktu & - & $100 \%$ & \\
\hline 9 & Sumber Belajar & & $100 \%$ & \\
\hline
\end{tabular}

Dengan melihat tabel distribusi prosentase hasil observasi tentang silabus di atas, yaitu materi ajar sebanyak $75 \%$, penentuan indikator keberhasilan sebanyak $75 \%$, jenis penilaian $75 \%$ dan sumber belajar sebanyak $100 \%$.

\section{Pengamatan}

Pengamatan dilakukan oleh kollaborator, pada siklus 1 pertemuan 1 dan 2 .Menurut observer peneliti sudah melaksanakan langkah-langkah Pembinaan Kolaboratif yang meliputi : mendengarkan, mempresentasikan, memecahkan masalah dan negoisasi. Pelaksanaan sangat kondusif karena antara Kepala Sekolah dan guru tidak kelihatan seperti sedang diadakan pembinaan, tetapi seperti sedang bekerja bersama tanpa ada yang merasa saling terbebani dan keterpaksaan.

\section{Evaluasi dan Refleksi}

Setelah proses pembinaan kolaboratif (mendengarkan, mempresentasikan, memecahkan masalah dan negoisasi) selesai dan guru-guru sudah mencoba membuat sendiri penyusunan pengembangan silabus, peneliti bersama guru melakukan refleksi terhadap pelaksanaan siklus I. Hasil refleksi terhadap pelaksanaan pembinaan dan pelatihan diidentifikasi bahwa tindakan 1 telah berlangsung dengan baik. Berdasarkan tabel distribusi prosentase hasil penyusunan pengembangan silabus, perlu adanya perbaikan yang meliputi penentuan materi pokok yang harus mengacu pada standar isi (SI) dan standar kompetensi lulusan (SKL), penentuan indikator keberhasilan masih adanya yang menemui kesulitan dalam menentukan kata-kata kerja operasional (KKO), penentuan jenis penilaian yang disesuaikan dengan indikator serta masih kurang bervariasi serta penentuan sumber belajar masih menyebutkan sumber yang relevan belum menunjukkan pada sumber belajar yang jelas. Guru baru menyadari kurang bervariasinya penentuan indikator keberhasilan setelah Kepala Sekolah membagikan daftar Kata-kata Kerja Operasional yang disarankan oleh Bloom, guru-guru hanya tinggal memilih dari daftar yang sudah ada. Selanjutnya bagi guru yang masih menemui kesulitan, dalam menentukan materi ajar, penentuan indikator keberhasilan dan sumber belajar, 
bersedia untuk diadakan pembinaan. Dan disepakati dilaksanakan pada pertemuan berikutnya.

Setelah proses pembinaan dan pelatihan selesai dan guru-guru sudah mencoba membuat sendiri pengembangan silabus, peneliti bersama guru melakukan refleksi terhadap pelaksanaan siklus I pertemuan 2. Hasil refleksi terhadap pelaksanaan pembinaan dan pelatihan diidentifikasi bahwa tindakan 2 telah berlangsung dengan baik. Berdasarkan tabel distribusi prosentase hasil penyusunan pengembangan silabus, dalam hal penentuan materi ajar sudah mengacu pada standar isi (SI) dan standar kompetensi lulusan (SKL), penentuan indikator keberhasilan sudah menggunakan kata-kata kerja operasional seperti yang disarankan oleh Bloom. Dalam menentukan sumber belajarpun sudah menyebutkan sumber belajar yang jelas, sehingga memudahkan bagi siapapun yang membaca untuk mendapatkan sumber belajar yang telah dituliskan dalam silabus. Berikut hasil kemajuan yang diraih para guru pada pertemuan I dan pertemuan 2 seperti pada tabel berikut:

Tabel 4. Distribusi Perbandingan Prosentase Hasil Observasi Tentang Kesesuaian Silabus Pada Siklus I, pertemuan 1 dan 2

\begin{tabular}{|c|c|c|c|c|c|c|}
\hline \multirow[t]{2}{*}{ No } & \multirow[t]{2}{*}{ Aspek Pengamatan } & \multicolumn{2}{|c|}{$\begin{array}{l}\text { Hasil } \\
\text { Pengamatan } 1\end{array}$} & \multicolumn{2}{|c|}{$\begin{array}{l}\text { Hasil } \\
\text { Pengamatan } 2\end{array}$} & \multirow[t]{2}{*}{ Ket } \\
\hline & & $\begin{array}{l}\text { Belum } \\
\text { Sesuai }\end{array}$ & Sesuai & $\begin{array}{l}\text { Belum } \\
\text { Sesuai }\end{array}$ & Sesuai & \\
\hline 1 & Identitas & - & $100 \%$ & - & $100 \%$ & \\
\hline 2 & Standar Kompetensi & - & $100 \%$ & - & $100 \%$ & \\
\hline 3 & Kompetensi Dasar & - & $100 \%$ & - & $100 \%$ & \\
\hline 4 & Materi Ajar & $50 \%$ & $50 \%$ & $25 \%$ & $75 \%$ & \\
\hline 5 & $\begin{array}{l}\text { Kegiatan } \\
\text { Pembelajaran }\end{array}$ & $75 \%$ & $25 \%$ & $25 \%$ & $75 \%$ & \\
\hline 6 & Indikator & $75 \%$ & $25 \%$ & $25 \%$ & $75 \%$ & \\
\hline 7 & Jenis Penilaian & $50 \%$ & $50 \%$ & $25 \%$ & $75 \%$ & \\
\hline 8 & Alokasi Waktu & - & $100 \%$ & - & $100 \%$ & \\
\hline 9 & Sumber Belajar & $25 \%$ & $75 \%$ & & $100 \%$ & \\
\hline
\end{tabular}

selesai dari yang direncanakan 2 kali

Dengan melihat tabel di atas, dari pengamatan 1 dan 2 sudah terlihat ada peningkatan yaitu tentang materi ajar dari $50 \%$ menjadi $75 \%$, Kegiatan pembelajaran meningkat dari $25 \%$ menjadi $75 \%$, Indikator dari $25 \%$ menjadi $75 \%$, jenis penilaian dari $50 \%$ menjadi $75 \%$. Dalam penelitian ini, peneliti mentargetkan kriteria keberhasilan adalah 75\%, berarti pada siklus I pertemuan 2 ini kriteria keberhasilan yang sudah ditetapkan sudah tercapai, maka pada pertemuan kedua ini untuk penyusunan pengembangan silabus dianggap sudah pertemuan. Untuk selanjutnya diteruskan pada siklus II tentang penyusunan pengembangan Rencana Pelaksanaan Pembelajaran (RPP).

\section{Siklus 2}

1. Perencanaan

Berdasarkan hasil refleksi siklus I pertemuan 2 disepakati bersama, bahwa guru setelah mampu menyusun pengembangan silabus yaitu sudah memperbaiki materi ajar yang sudah disesuaikan dengan standar isi (SI) dan standar kompetensi lulusan (SKL), jeniis penilaian, dan penentuan indikator 
keberhasilan yaitu dengan memperbaiki menggunakan kata-kata kerja operasional (KKO) sesuai dengan daftar Kata-kata Kerja Operasional yang disarankan oleh Bloom serta melengkapi sumber bahan. Hasil dari perbaikan penyusunan pengembangan silabus merupakan dasar untuk menyusun pengembangan Rencana Pelaksanaan Pembelajaran (RPP) sebagai bekal untuk pelaksanaan pembelajaran di kelas dengan lebih terperinci, terutama dalam hal penentuan indikator keberhasilan pencapaian kompetensi.

\section{Pelaksanaan}

Siklus II pertemuan 1 ini dilaksanakan pada hari Kamis tanggal 16 Agustus 2018 pukul 08.00 s.d 11.00

WIB. Kegiatan pembinaan penyusunan RPP dilakukan dengan berbekal pengetahuan dan kemampuan dalam penyusunan silabus, serta membawa silabus yang sudah dibuat sendiri pada siklus I serta membawa sumber bahan. Sebelum masuk ke materi Rencana
Pelaksanaan Pembelajaran (RPP) terlebih dahulu peneliti menanyakan dan berdiskusi dengan guruguru,apakah di antara guru-guru ada yang masih mengalami kesulitan untuk memperbaiki hasil refleksi I, melalui strategi tersebut guru merasakan bahwa penyusunan silabus tidak sulit, dan tidak merasa terbebani asal ada motivasi diri yang kuat untuk menjadi guru yang profesional dan memberikan pengetahuan dan pengalaman terbaik pada siswa-siswanya. Pembinaan penyusunan RPP ini dilaksanakan secara kondusif, guru-guru begitu antusias untuk mencoba membuat Rencana Pelaksanaan Pembelajaran (RPP) sendiri. Untuk mengetahui hasil pekerjaan guru dalam penyusunan pengembangan Rencana Pelaksanaan Pembelajaran (RPP) yaitu kesesuaian antara pekerjaan guru dengan aturan yang sudah ditetapkan oleh Badan Standar Nasional Pendidikan, di bawah ini peneliti sajikan pada tabel 5 yaitu sebagai berikut :

Tabel 5. Distribusi Prosentase Hasil Observasi Tentang Kesesuaian Rencana Pelaksanaan Pembelajaran (RPP) Pada Siklus II, pertemuan 1

\begin{tabular}{|c|c|c|c|c|}
\hline \multirow[b]{2}{*}{ No } & \multirow[b]{2}{*}{ Aspek Pengamatan } & \multicolumn{2}{|c|}{ Hasil Pengamatan } & \multirow[b]{2}{*}{ Keterangan } \\
\hline & & $\begin{array}{l}\text { Belum } \\
\text { Sesuai }\end{array}$ & Sesuai & \\
\hline 1 & Mata Pelajaran & - & $100 \%$ & \\
\hline 2 & Kelas/Semester & - & $100 \%$ & \\
\hline 3 & Pertemuan ke...... & $0 \%$ & $100 \%$ & \\
\hline 4 & Alokasi Waktu & $25 \%$ & $75 \%$ & \\
\hline 5 & Standar Kompetensi & & $100 \%$ & \\
\hline 6 & Kompetensi Dasar & & $100 \%$ & \\
\hline 7 & Indikator & $75 \%$ & $25 \%$ & \\
\hline 8 & Tujuan Pembelajaran & $50 \%$ & $50 \%$ & \\
\hline 9 & Materi Ajar & $75 \%$ & $25 \%$ & \\
\hline 10 & Metode Pembelajaran & $50 \%$ & $50 \%$ & \\
\hline \multirow[t]{5}{*}{11} & Langkah-langkah & & & \\
\hline & Pembelajaran & & & \\
\hline & a. Kegiatan Awal & $50 \%$ & $50 \%$ & \\
\hline & b. Kegiatan Inti & $75 \%$ & $25 \%$ & \\
\hline & c. Kegiatan Akhir & $50 \%$ & $50 \%$ & \\
\hline
\end{tabular}




\begin{tabular}{lllc}
\hline \multirow{2}{*}{ No } & Aspek Pengamatan & \multicolumn{2}{c}{ Hasil Pengamatan } \\
\cline { 3 - 4 } & $\begin{array}{c}\text { Belum } \\
\text { Sesuai }\end{array}$ & Sesuai & Keterangan \\
\hline 12 & $\begin{array}{l}\text { Alat/Bahan/Sumber } \\
\text { Belajar }\end{array}$ & $25 \%$ & $75 \%$ \\
\hline 13 & Penilaian & $75 \%$ & $25 \%$ \\
\hline
\end{tabular}

Dari data tabel di atas yaitu hasil dari penyusunan Rencana Pelaksanaan Pembelajaran (RPP), bahwa dalam kegiatan inti guru ada yang belum memperhatikan beberapa hal, antara lain : bagaimana mengaktifkan siswa,bagaimana siswa membangun peta konsep, bagaimana mengumpulkan informasi dengan stimulus pertanyaan efektif, bagaimana menggali informasi dari media massa, bagaimana membandingkan dan mensintesiskan informasi, bagaimana melakukan kerja praktek dan sebagainya. Dalam kegiatan pembelajaran yaitu dalam kegiatan inti baru diperoleh hasil sebanyak $25 \%$ hal ini, menunjukkan bahwa guru belum banyak mengenal berbagai bentuk model pembelajaran. Dalam mengembangkan kegiatan pembelajaran masih nampak belum bervariasi yang melalui proses ekplorasi, elaborasi dan konfirmasi. Hal ini terjadi karena belum dipahami secara mendalam mengenai kegiatan yang seharusnya dilakukan oleh guru untuk memberikan pengalaman belajar kepada siswa serta menentukan model pembelajaran. Penentuan pengalaman belajar akan memberikan banyak pengaruh terhadap sumber belajar maupun di mana siswa akan belajar. Untuk mengatasi hal tersebut peneliti mengajak guru-guru untuk mendiskusikan suatu model pembelajaran dengan kompetensi dasar dan indikator yang sesuai dengan Standar Isi.

Dalam penentuan penilaianpun guru baru mencapai $25 \%$, peneliti temukan belum sinkronnya antara indikator pencapaian kompetensi dengan bentuk soal yang dibuat, termasuk pedoman penilaianpun skore yang dibuat belum disesuaikan dengan bobot soal hanya disamakan masing-masing soal skorenya 4, padahal bobot soal berbedabeda, demikian juga dalam membuat kunci jawabanpun masih ada yang terkesan asal-asalan, demikian juga dalam penggunaan metode diskusi dan unjuk kerja masih ada yang belum membuat pedoman penilaiannya. Hal lain yang ditemui adalah belum ditemukan langkah tindak lanjut dari hasil pembelajaran yaitu bagi yang nilainya masih kurang belum ada soal ataupun tugas remidi demikian juga bagi yang sudah mendapatkan nilai yang bagus belum ada soal ataupun tugas pengayaan. Dalam pelaksanaan pembinaan ini para guru begitu antusias terbukti dengan adanya beberapa guru yang mengajukan pertanyaan dan berdiskusi dengan sesama guru serta menyadari betapa perlunya membuat sendiri Rencana Pelaksanaan Pembelajaran (RPP) sehingga tahu persis apa yang akan dilakukan selama pembelajaran berlangsung, serta menyadari kekeliruannya selama ini yang tidak hanya sebagai syarat administrasi saja,tetapi lebih memiliki arti penting dalam pelaksanaan proses pembelajaran sehingga apa yang akan dilaksanakan sudah terencana dan disesuaikan dengan situasi dan kondisi sekolah sendiri yaitu dengan menerapkan Kurikulum Tingkat Satuan Pendidikan (KTSP), sehingga sekolah diberi keleluasaan untuk mengembangkan sendiri kurikulum tanpa mengurangi substansi standar isi. 
Sebelum mulai Pembinaan pada siklus II pertemuan 2 ini Kepala Sekolah masih mengajak untuk berdiskusi tentang kelemahan pada siklus II pertemuan 1, dan masih menanyakan kalau masih menemui kesulitan. Pada umumnya guru-guru sudah mengetahui kelemahannya masing-masing sehingga mereka langsung mendiskusikan dan mencari solusi tentang kesulitankesulitan yang masih ditemui. Dalam hal menentukan model pembelajaran yang tepat untuk setiap kompetensi yang akan dicapai memang tidak mudah, harus betul-betul disesuaikan dengan kondisi yang hadapi seperti karakter siswa, yang memiliki minat belajar rendah, kelengkapan sarana, kemampuan guru dan lain-lain. Agar lebih jelas hasil Pembinaan pada siklus II pertemuan 2 ini, peneliti sajikan pada tabel 6 di bawah ini, yaitu sebagai berikut :

Tabel 6. Distribusi Prosentase Hasil Observasi Tentang Kesesuaian Rencana Pelaksanaan Pembelajaran (RPP) Pada Siklus II, pertemuan 2

\begin{tabular}{|c|c|c|c|}
\hline \multirow{2}{*}{ No } & \multirow{2}{*}{ Aspek Pengamatan } & Hasil Pengamatan & \multirow{2}{*}{ Keterangan } \\
\hline & & Belum Sesuai & \\
\hline 1 & Mata Pelajaran & & $100 \%$ \\
\hline 2 & Kelas/Semester & & $100 \%$ \\
\hline 3 & Pertemuan ke...... & & $100 \%$ \\
\hline 4 & Alokasi Waktu & & $100 \%$ \\
\hline 5 & Standar Kompetensi & & $100 \%$ \\
\hline 6 & Kompetensi Dasar & & $100 \%$ \\
\hline 7 & Indikator & $25 \%$ & $75 \%$ \\
\hline 8 & Tujuan Pembelajaran & $25 \%$ & $75 \%$ \\
\hline 9 & Materi Ajar & $25 \%$ & $75 \%$ \\
\hline 10 & Metode Pembelajaran & $25 \%$ & $75 \%$ \\
\hline \multirow[t]{5}{*}{11} & Langkah-langkah & & \\
\hline & Pembelajaran & & \\
\hline & a. Kegiatan Awal & & $100 \%$ \\
\hline & b. Kegiatan Inti & $25 \%$ & $75 \%$ \\
\hline & c. Kegiatan Akhir & & $100 \%$ \\
\hline 12 & $\begin{array}{l}\text { Alat/Bahan/Sumber } \\
\text { Belajar }\end{array}$ & $25 \%$ & $75 \%$ \\
\hline 13 & Penilaian & $25 \%$ & $75 \%$ \\
\hline
\end{tabular}

Dengan melihat hasil dari tabel $4.6 \mathrm{di}$ atas, dari kesulitan yang dihadapi sebagian guru pada siklus II pertemuan 1 guru sudah mampu untuk mengatasi kesulitan masing-masing diantaranya, penentuan metode pembelajaran sudah mencapai hasil sebanyak $75 \%$, Kegiatan inti dalam hal ini menentukan model pembelajaran sudah mencapai hasil sebanyak $75 \%$, dan aspek penilaian sudah mencapai hasil sebanyak $75 \%$. Pelaksanaan kali ini guru-guru sangat bersemangat untuk segera menyesaikan pekerjaannya. Setelah selesai diadakan refleksi. Siklus II pertemuan 2 ini dilaksanakan pada Hari Sabtu tanggal 18 Agustus 2018 Menurut pengamatan dari kolaborator, peneliti sudah melaksanakan langkahlangkah Pembinaan Kolaboratif yang meliputi : mendengarkan, mempresentasikan, memecahkan masalah dan negoisasi, suasana begitu kondusif pengawas dan guru merasa senang karena sudah tidak banyak mengalami kesulitan yang berarti. 


\begin{tabular}{|c|c|c|c|c|c|c|}
\hline \multirow[b]{2}{*}{ No } & \multirow[b]{2}{*}{ Aspek Pengamatan } & \multicolumn{2}{|c|}{$\begin{array}{c}\text { Hasil } \\
\text { Pengamatan } 1 \\
\end{array}$} & \multicolumn{2}{|c|}{$\begin{array}{c}\text { Hasil } \\
\text { Pengamatan } 2 \\
\end{array}$} & \multirow[t]{2}{*}{ Keter } \\
\hline & & $\begin{array}{l}\text { Belum } \\
\text { Sesuai }\end{array}$ & Sesuai & $\begin{array}{l}\text { Belum } \\
\text { Sesuai }\end{array}$ & Sesuai & \\
\hline 1 & Mata Pelajaran & - & $100 \%$ & & $100 \%$ & \\
\hline 2 & Kelas/Semester & - & $100 \%$ & & $100 \%$ & \\
\hline 3 & Pertemuan ke...... & & $100 \%$ & & $100 \%$ & \\
\hline 4 & Alokasi Waktu & $25 \%$ & $75 \%$ & & $100 \%$ & \\
\hline 5 & Standar Kompetensi & & $100 \%$ & & $100 \%$ & \\
\hline 6 & Kompetensi Dasar & & $100 \%$ & & $100 \%$ & \\
\hline 7 & Indikator & $75 \%$ & $25 \%$ & $25 \%$ & $75 \%$ & \\
\hline 8 & Tujuan Pembelajaran & $50 \%$ & $50 \%$ & $25 \%$ & $75 \%$ & \\
\hline 9 & Materi Ajar & $75 \%$ & $25 \%$ & $25 \%$ & $75 \%$ & \\
\hline 10 & Metode Pembelajaran & $50 \%$ & $50 \%$ & $25 \%$ & $75 \%$ & \\
\hline \multirow[t]{5}{*}{11} & Langkah-langkah & & & & & \\
\hline & Pembelajaran & & & & & \\
\hline & a. Kegiatan Awal & $50 \%$ & $50 \%$ & & $100 \%$ & \\
\hline & b. Kegiatan Inti & $75 \%$ & $25 \%$ & $25 \%$ & $75 \%$ & \\
\hline & c. Kegiatan Akhir & $50 \%$ & $50 \%$ & & $100 \%$ & \\
\hline 12 & $\begin{array}{l}\text { Alat/Bahan/Sumber } \\
\text { Belajar }\end{array}$ & $25 \%$ & $75 \%$ & $25 \%$ & $75 \%$ & \\
\hline 13 & Penilaian & $75 \%$ & $25 \%$ & $25 \%$ & $75 \%$ & \\
\hline
\end{tabular}

3. Evaluasi dan Refleksi

Berdasarkan perencanaan, tindakan dan pengamatan pada siklus II, peneliti dan guru-guru bertemu untuk mengadakan refleksi. Disepakati bersama bahwa beberapa guru masih memerlukan pembinaan kegiatan pembelajaran yaitu pengembangan kegiatan inti dalam hal menentukan model pembelajaran yang tepat dan aspek penilaian. Penentuan refleksi disepakati pada siang hari, sesudah pelaksanaan diskusi. Pelaksanaan kegiatan refleksi kali ini diadakan sangat kondusif karena dilaksanakan dengan santai seperti sedang ngobrol biasa diselingi dengan guyonan-guyonan, tanpa menghilangkan tujuan dari refleksi materi tentang penyusunan pengembangan Rencana Pelaksanaan Pembelajaran (RPP). Untuk lebih jelasnya peningkatan kemampuan guru dalam penyusunan pengembangan Rencana Pelaksanaan Pembelajaran (RPP) berdasarkan hasil pengamatan pada siklus II, pertemuan 1 dan 2 dapat dilihat pada tabel. 7 di bawah ini

Tabel 7. Distribusi Perbandingan Prosentase Hasil Observasi Tentang Kesesuaian Rencana Pelaksanaan Pembelajaran (RPP) Pada Siklus II, pertemuan 1 dan 2

Berdasarkan tabel 4.7 di atas, pengembangan kegiatan inti dalam hal ini menentukan model pembelajaran sudah ada peningkatan yaitu : dari $25 \%$ meningkat menjadi $75 \%$ dan aspek penilaian dari $25 \%$ meningkat menjadi $75 \%$, Indikator meningkat dari 25\% menjadi $75 \%$, tujuan pembelajaran meningkat dari 50\% menjadi $75 \%$, materi ajar dari 25\% menjadi $75 \%$. Target pencapaian hasil yang ditetapkan oleh peneliti sebanyak $75 \%$ guru-guru mampu membuat Rencana Pelaksanaan Pembelajaran (RPP) sendiri sudah tercapai. Dengan demikian pada siklus II pertemuan kedua ini dianggap telah selesai. 


\section{Pembahasan}

Dalam penelitian ini, peneliti memilih model Pembinaan Kolaboratif dengan harapan terjadi kontrak antara pengawas dan guru, karena dalam pola Pembinaan Kolaboratifada kedaulatan yang seimbang antara pengawas dan guru, yang memiliki tanggung jawab masing-masing sama-sama sedang. Dalam pandangan Kolaboratifini, perilaku pokok pengawas mencakup : mendengarkan, mempresentasikan, memecahkan masalah dan negosiasi. Dalam pembahasan ini peneliti sampaikan langkah-langkah yang telah dilakukan dalam rangka Pembinaan guru tentang penyusunan pengembangan silabus dan rencana pelaksanaan pembelajaran.

Dengan mendengarkan semua kesulitan-kesulitan yang dihadapi oleh guru, yaitu tentang penyusunan pengembangan silabus dan pengembangan Rencana Pelaksanaan Pembelajaran (RPP) guru-guru merasa mendapatkan perhatian,dan kesulitannya didengar sehingga menjadi lebih terbuka untuk mengemukakan kesulitannya masing-masing. Kesulitankesulitan yang dihadapi guru diinventarisir dan diolah, setelah itu Pengawas mempresentasikan tentang pentingnya membuat perencanaan pembelajaran sendiri yang sesuai dengan kompetensi yang ingin dicapai agar tahu persis apa yang akan dilakukan sesuai dengan situasi dan kondisi serta sarana dan prasarana yang tersedia. Dengan demikian guru menyadari kekeliruannya selama ini, yang hanya memfotokopi silabus dan RPP dan belum dijadikan sebagai pedoman dalam mengajar.

Setelah guru menyadari kekeliruannya selama ini,mereka ingin mencoba menyusun pengembangan silabus dan RPP sendiri dan bersedia untuk diadakan Pembinaan secara klasikal dan berdasarkan kesepakatan diadakan dua kali yang pertama tentang penyusunan pengembangan silabus dan yang kedua penyusunan pengembangan rencana pelaksanaan pembelajaran.

Data hasil penelitian ini diketahui bahwa pembuatan perencanaan pembelajaran dilaksanakan melalui 2 siklus yaitu :

1. Siklus I, dilaksanakan dalam 2 kali pertemuan, pada pertemuan 1 setelah selesai diadakan refleksi, dan diperoleh data bahwa penentuan materi ajar, menentuan indikator keberhasilan dan menentukan sumber belajar masih kurang dari target keberhasilan pada penelitian ini, maka untuk materi yang masih kurang dilanjutkan pada pertemuan 2 , setelah selesai pertemuan 2 diadakan refleksi untuk menentukan apakah masih perlu ada pertemuan 3 atau tidak.

Dengan melihat tabel 4.4 di atas, sudah terlihat ada peningkatan yaitu tentang materi ajar dari $50 \%$ menjadi $75 \%$, Kegiatan pembelajaran meningkat dari $25 \%$ menjadi $75 \%$, Indikator dari $25 \%$ menjadi $75 \%$, jenis penilaian dari $50 \%$ menjadi $75 \%$. Dalam penelitian ini, peneliti mentargetkan kriteria keberhasilan adalah $75 \%$, berarti pada siklus I pertemuan 2 ini kriteria keberhasilan yang sudah ditetapkan sudah tercapai, maka pada pertemuan kedua ini untuk penyusunan pengembangan silabus dianggap sudah selesai.lanjutnya diteruskan pada siklus II tentang penyusunan pengembangan Rencana Pelaksanaan Pembelajaran (RPP).

2. Siklus II dilaksanakan dalam 2 kali pertemuan, pada pertemuan 1 
setelah selesai pengamatan diadakan refleksi, dan diperoleh data bahwa : dalam kegiatan inti yaitu belum merencanakan kegiatan yang bisa mengaktifkan siswa dalam hal ini menentukan model pembelajaran, demikian juga dalam menentukan aspek penilaian masih ditemukan belum adanya kesesuaian antara materi pembelajaran dengan bentuk soal yang dibuat termasuk dalam menentukan skore penilaian. Dengan telah ditemukan kekurangan pada pertemuan 1 ini, maka untuk materi yang masih kurang dilanjutkan pada pertemuan 2, setelah selesai pada pertemuan 2 hasilnya dikumpulkan, diteliti dan dianalisa, setelah itu diadakan refleksi untuk menentukan pada tahap berikutnya.

Berdasarkan tabel 4.7 di atas, pengembangan kegiatan inti dalam hal ini menentukan model pembelajaran sudah ada peningkatan yaitu : dari $25 \%$ meningkat menjadi $75 \%$ dan aspek penilaian dari $25 \%$ meningkat menjadi $75 \%$, Indikator meningkat dari $25 \%$ menjadi $75 \%$, tujuan pembelajaran meningkat dari $50 \%$ menjadi $75 \%$, materi ajar dari $25 \%$ menjadi $75 \%$. Target pencapaian hasil yang ditetapkan oleh peneliti sebanyak $75 \%$ guru-guru mampu membuat Rencana Pelaksanaan Pembelajaran (RPP) sendiri sudah tercapai. Dengan demikian pada siklus II pertemuan kedua ini dianggap telah selesai.

Dengan demikian dalam penelitian ini, dapat menjawab rumusan masalah yang dikemukakan oleh peneliti yaitu upaya yang digunakan oleh Kepala Sekolah agar guru-guru sebelum mengajar membuat perencanaan pembelajaran adalah dengan cara memberikan

Pembinaan dan cara yang digunakan oleh Kepala Sekolah adalah cara pembinaan dengan Kolaboratif, karena antara Kepala Sekolah dan guru sama-sama memiliki tanggung jawab. Kepala Sekolah memberikan motivasi agar sebelum mengajar sudah menyusun pengembangan pembelajaran yang dibuat sendiri sehingga pada pelaksanaan pembelajaran lebih percaya diri, terprogram dan sesuai dengan situasi dan kondisi sekolah serta sarana dan prasarana yang tersedia serta untuk memenuhi tuntutan kompetensi profesionalisme dan kompetensi pedagogik seorang pendidik,dengan demikian tujuan akhir adalah prestasi siswa baik. Dari hasil penelitian ini diperoleh adanya peningkatan kemampuan guru-guru dalam membuat perencanaan pembelajaran meliputi penyusunan pengembangan silabus dan Rencana Pelaksanaan Pembelajaran (RPP) setelah diberikan pembinaan secara Kolaboratif oleh Kepala Sekolah.

\section{KESIMPULAN}

Dari hasil penelitian maka dapat disimpulkan bahwa melalui supervisi akademik yang berkelanjutan sebagai berikut :

1. Terdapat peningkatan kemampuan/kompetensi guru dalam menyusun perencanaan pembelajaran sebelum ada supervisi dan setelah dilaksanakan supervisi yaitu pada penyusunan silabus komponen penentuan materi ajar dari $50 \%$ menjadi 75 $\%$, Kegiatan pembelajaran meningkat dari $25 \%$ menjadi $75 \%$, Indikator dari $25 \%$ menjadi $75 \%$, jenis penilaian dari $50 \%$ menjadi 75\%.Sedangkan pada penyusunan RPP ada peningkatan dalam hal 
menentukan model pembelajaran sudah ada peningkatan yaitu : dari $25 \%$ meningkat menjadi $75 \%$ dan aspek penilaian dari $25 \%$ meningkat menjadi $75 \%$, Indikator meningkat dari 25\% menjadi $75 \%$, tujuan pembelajaran meningkat dari 50\% menjadi $75 \%$, materi ajar dari $25 \%$ menjadi $75 \%$.

2. Proses yang mengakibatkan terjadinya peningkatan kompetensi guru dalam menyusun silabus dan (RPP) tersebut meliputi langkahlangkah sebagai berikut :

a. Pengumuman rencana supervise terhadap guru

b. Pelaksanaan supervise individual, dimana setiap guru diminta mempresentasikan silabus dan RPP-nya kepada kepala sekolah kemudian kepala sekolah memberi masukan pembinaan kepada semua guru tentang kekurangan silabus dan RPP

c. Untuk mengecek originalitas silabus dan RPP yang disusun guru, kepala sekolah melakukan supervise kelas. Hal ini dilakukan untuk menyesuaikan rencana yang dibuat dalam silabus dan RPP dengan penerapannya di kelas. Jika sesuai maka dapat dipastikan kompetensi guru dalam menyusun silabus dan RPP tersebut benar (bukan jiplakan atau copy paste dari orang lain). Jika banyak ketidak sesuaian maka ada kemungkinan silabus dan RPP tersebut dibuat oleh orang lain

3. Peningkatan guru dalam menyusun silabus dan RPP adalah sebagai berikut :

a. Silabus ada peningkatan dari siklus pertama ke siklus kedua dari rata-rata $37,5 \%$ menjadi
$75 \%$ yaitu sebesar 37,5 \% (peningkatanya $50 \%$ )

b. RPP ada peningkatan dari siklus pertama ke siklus kedua dari rata-rata $30 \%$ menjadi $75 \%$ yaitu sebesar $45 \%$ (peningkatanya 60)

\section{DAFTAR PUSTAKA}

Aqib, Zainal. (2002). Profesionalisme guru dalam pembelajaran. Surabaya: Insan Cendikia.

Dahono. (2015). Peningkatan peran kepala sekolah sebagai supervisor melalui bimbingan berkelanjutan di gugus ki hajar dewantara upt dinas pendidikan kecamatan kledung. Jurnal Pendidik dan Profesi Pendidik.

Majid, Abdul. (2005). Perencanaan pembelajaran mengembangkan standar kompetensi guru. Bandung: PT Remaja Rosdakarya.

Mangkunegara, Anwar Prabu. (2002). Manajemen sumber daya manusia. Bandung: PT. Remaja Rosda Karya.

Sedarmayanti. (2004). Manajemen sumber daya manusia. Yogyakarta: Liberty.

Septiyan, G. (2017). Pengaruh model teams games tournament terhadap keterampilan pengambilan keputusan dalam pembelajaran ips di sekolah dasar. Mimbar Sekolah Dasar, 4(1), 106-116. doi:http://dx.doi.org/10.23819/mi $\underline{\text { mbar-sd.v4i1.5547 }}$ 